\title{
DITADURA E REPRESSÃO: LOCAIS DE RECORDAÇÃO E MEMÓRIA SOCIAL NA CIDADE DE SÃO PAULO
}

\author{
Janaína de Almeida Teles \\ Universidade de São Paulo (USP), São Paulo, SP - Brasil. \\ <janateles@uol.com.br>
}

http://dx.doi.org/10.1590/ 0102-6445191-220/96

$\mathrm{Na}$ atualidade, a relação entre história e memória e a reflexão sobre o passado e os processos de mudança social tornaram-se uma preocupação central. Podemos dizer que a "cultura da memória" (Huyssen, 2002), assim como as políticas de memória tornaram-se transnacionais, senão globais. Tornou-se lugar comum considerar que o sentido do que passou não está fixado, o passado está constantemente aberto às disputas de interpretação do que ocorreu (Ricoeur, 2007).

A emergência da memória de traumas históricos no espaço público durante o século XX, sobretudo após a Segunda Guerra Mundial, deu lugar ao desenvolvimento de uma estética do que se tornou conhecido como antimonumento, a qual visa fundir a tradição do monumento com a da comemoração fúnebre (Seligmann-Silva, 2012). Desde a Antiguidade, a tradição de construção de monumentos esteve ligada mais à comemoração de vitórias bélicas e a heróis do que à ideia de advertir ${ }^{1}$. No antimonumento, porém, seu

\footnotetext{
1 O termo monumento vem do verbo latino monere que significa "fazer recordar", de onde deriva avisar, iluminar, instruir (cf. Le Goff, 1994, p. 535).
} 
sentido heroico "é totalmente modificado e deslocado para um local de lembrança” (Seligmann-Silva, 2012, p. 23), de admoestação da violência e de homenagem aos mortos.

Esse esforço de crítica da "heroicização" levou a que diversos "lugares de memória" (Nora, 1993, pp. 21-22) tivessem por objeto a legitimação de instituições e valores de grupos vilipendiados no passado. Em muitos casos, porém, mais do que representar uma ruptura com a tradição, a "cultura da memória" indica que os excessos de atrocidades cometidos, sobretudo durante a Segunda Guerra, "implodem a capacidade humana de apreender e representar" (Assmann, 2011, p. 361).

É de se ter em vista que, se por um lado tal ritualística representa uma via à experiência originária da cultura, por outro traz o risco da reificação, desde a transformação do registro histórico em objeto neutralizado e rentável (Traverso, 2007, p. 68). Em muitos casos, esses instrumentos de 192 (re)memoração continuam a transmitir narrativas oficiais sobre o passado. Como toda narrativa, as versões oficiais são seletivas, embora nem todas devam ser consideradas tão enviesadas ideologicamente quanto a maioria das versões oficiais da história (Winter, 2006). Ressaltar certos traços com sinais de heroísmo implica silenciar outros, especialmente os erros e as derrotas. Porém, diante da narrativa oficial transmitida pela educação formal, constroem-se também relatos e sentidos diferentes do passado, mantidos pela memória e a transmissão oral, práticas de resistência diante do poder, muitas vezes constituídos nos âmbitos da intimidade ou da clandestinidade (Jelin, 2002, pp. 39-42).

Esse debate em torno da atribuição de sentido do passado está profundamente vinculado à análise dos processos e atores sociais envolvidos na construção das memórias, especialmente sobre feitos notáveis, cujos efeitos perduram no tempo e no espaço. Neste artigo, trataremos da construção dos primeiros "locais de recordação" relativos à repressão 
ditatorial na cidade de São Paulo, focando nossas análises nos processos históricos que os inauguraram. Consideraremos aqui a caracterização desses locais, tendo em vista as multiplicidades de vozes e perspectivas ancoradas na significação de "lugares traumáticos" (Assmann, 2011, p. 351).

Ressalte-se que, no Brasil, a recuperação factual sobre a repressão política empreendida durante a ditadura, assim como a reflexão sobre os sentidos desse passado permanecem inconclusas. A despeito dos esforços empenhados pela Comissão Nacional da Verdade, que fundamentalmente sistematizou as informações já existentes sobre o período ditatorial (CNV, 2014), falta-nos um levantamento exaustivo sobre as pessoas assassinadas ou punidas por razões políticas, as circunstâncias de tais crimes e seus responsáveis.

A negação do direito à verdade e à justiça, assim como as limitações existentes nas políticas de reparação relativas ao passado recente têm dificultado ou impedido a articulação e transmissão das memórias desses anos de violência, fundamentais para a construção de um referencial crítico sobre o período. Nesse contexto, contudo, insere-se o crescente debate sobre as heranças da repressão ditatorial no Brasil, tal como veremos a seguir.

\section{O projeto Brasil Nunca Mais e as disputas pelas memórias da ditadura}

A transição brasileira para a democracia ocorreu sem rupturas evidentes, pautada pela conciliação entre as elites civis e militares, após se assegurarem de que não se remexeria profundamente no passado. Esse pacto limitou a apuração dos crimes da ditadura e a constituição das memórias sobre aquele momento. Não obstante, alguns atores sociais buscaram exibir marcas simbólicas e efetivas de rompimento com o período anterior, sistematizando e divulgando as denúncias dos crimes da ditadura, tendo em vista propostas e mecanismos de recuperação factual e judicial, bem como de memórias. 
As transições políticas influenciam a construção do legado do regime político anterior, na medida em que esses momentos de mudança na relação entre Estado e sociedade representam "atos fundacionais", nos quais entram em conflito novas e velhas leituras do passado (Jelin, 2002, pp. 43-44). No Brasil pós-ditadura, as disputas pelas memórias foram marcadas por dois marcos inaugurais: a publicação do relatório do projeto Brasil Nunca Mais, em 1985, e a abertura da vala clandestina de Perus, em 1990 (Teles, 2012).

O livro Brasil: Nunca Mais inaugurou as operações de memória sobre a ditadura no período de redemocratização. O projeto foi idealizado por advogados de defesa e organizado por ex-presos políticos, jornalistas e historiadores, com o apoio decisivo de dom Paulo Evaristo Arns e do reverendo Jaime Wright. Entre 1979 e 1985, membros do projeto lograram copiar secretamente 707 processos completos e 194 dezenas de outros incompletos, encontrados nos arquivos da Justiça Militar desde 1964, reunindo cerca de 1,2 milhão de páginas de documentos produzidos pelo aparato repressivo ou por ele apropriado de grupos dissidentes (Arns e Projeto Brasil Nunca Mais, 1985).

Essa obra favoreceu a constituição de uma consciência coletiva acerca da política repressiva do período e do status dos sobreviventes. Baseado nessa vasta documentação, o livro pôde ser instrumentalizado para a formação escolar e acadêmica, assim como para a sistematização de denúncias de abusos dos direitos humanos, ao longo dos últimos trinta anos (Capelato, 2007, pp. 14-17).

Parte disso foi possível porque parcela dos perseguidos políticos submetidos aos "tribunais de exceção", controlados pela Justiça Militar desde 1965, fizeram declarações em juízo que continham denúncias das torturas sofridas, nas quais mencionavam os nomes dos torturadores e os métodos de sevícia empregados (Arquidio- 
cese, 1987, p. 25) ${ }^{2}$. Desse modo, a ditadura acabou por documentar parte das violações aos direitos humanos que praticava, mantendo esses documentos em arquivo no Supremo Tribunal Militar.

A obra revelou, com provas irrefutáveis, a atuação do terrorismo de Estado instaurado em 1964 e suas estratégias de repressão. A utilização exclusiva de fontes oficiais é a característica principal assinalada pelos seus organizadores e o fator decisivo que garantiu à obra confiabilidade e legitimidade (Arquidiocese, 1987, pp. 22-24). Não obstante, o caráter oficial da documentação e, principalmente, sua origem nos "tribunais de exceção" forneceram informações com determinadas características, que pouco acrescentaram ao esclarecimento dos assassinatos sob tortura, sobretudo ao dos desaparecimentos forçados.

O Brasil Nunca Mais refletiu as ambiguidades e limites da transição política brasileira que ainda marcam a construção das memórias sobre a ditadura. Inicialmente, a equipe do projeto resolveu adiar a publicação do livro para até depois da posse do presidente civil eleito indiretamente pelo Congresso Nacional, Tancredo Neves, marcada para 15 de março de 1985. Eles não queriam arriscar-se a provocar o cancelamento da posse e represálias dos militares. Com a doença de Tancredo, o lançamento do livro foi adiado para 15 de julho, quando chegou às livrarias (Weschler, 1990, p. 75).

Foi preciso esperar até o dia 21 de novembro daquele ano para liberar aos jornalistas a lista dos torturadores, pois se decidiu suspender a publicação dos 444 nomes no livro até que a situação política se afirmasse. Esse levantamento era uma continuidade das listas elaboradas pelos

\footnotetext{
2 Mesmo sob ameaça de voltarem a ser torturados, 1.843 pessoas (25\% dos réus) revelaram as torturas e assassinatos a que foram submetidos ou testemunharam (cf. Arquidiocese, 1987, p. 13).
} 
presos políticos ao longo da década de 1970 (Teles, 2011). Nos dois anos seguintes, o Brasil: Nunca Mais foi a obra literária mais vendida do país, superando a marca de 300 mil exemplares ${ }^{3}$.

O projeto Brasil Nunca Mais (BNM) representou um claro empecilho ao acobertamento dos crimes da ditadura, ainda que seus desdobramentos políticos e institucionais tenham sido tímidos. A despeito de suas consequências práticas limitadas, os ecos traumáticos das denúncias das violações compiladas no relatório do projeto desempenharam papel decisivo na percepção da sociedade civil acerca da extensão dos crimes cometidos pela ditadura, assim como na sua condenação moral. Essa percepção tem ajudado na limitação do poder e do espaço concedidos às Forças Armadas, no âmbito do aparato burocrático do Estado. A contribuição do BNM é a de possibilitar à sociedade brasileira lidar com o legado da ditadura de um ponto de vista jurídico, histórico e cultural.

196 Desde 1975, mas sobretudo a partir da campanha pela anistia ampla, geral e irrestrita, os presos políticos adquiriram o reconhecimento de "prisioneiros de consciência" de parte da sociedade civil e considerável parcela da imprensa. A despeito dos esforços empenhados pelo movimentos de anistia, estes não conseguiram impedir que a anistia parcial de 1979 fosse considerada "recíproca" ${ }^{4}$. Ainda que tais esforços tenham logrado impor desgaste à ditadura, a "teoria dos dois demônios" ganhou repercussão no Brasil, igualando, equivocada e injustamente, violência de Estado e violência revolucionária. Os partidários da ditadura difundiram, com

\footnotetext{
3 As 38 edições sucederam-se até 2009 e, a partir de 2013, seus originais encontram-se digitalizados e disponíveis pela internet. Em 1987, uma cópia do material do projeto foi doado ao Arquivo Edgard Leuenroth (AEL), da Unicamp. E, em 2011, o Ministério Público Federal (MPF-SP) disponibilizou os originais para acesso na internet.

4 Esta interpretação da Lei de Anistia (1979) tornou-se hegemônica, tendo sido reafirmada pelo Supremo Tribunal Federal em 2010 (cf. ADPF 153, disponível em: $<$ http://www.stf.jus.br/arquivo/cms/noticianoticiastf/anexo/adpf153.pdf >).

5 Cf. introdução de Nunca Más (Conadep, 2006) e Crenzel (2008).
} 
relativo sucesso, a tese de que teria havido uma "guerra fratricida" no país, na qual "dois lados" enfrentaram-se, favorecendo a visão de que, na transição para a democracia, os chamados "radicais" de direita e de esquerda deveriam ser igualmente repudiados.

Disseminou-se, assim, a ideia de que houve concessão da anistia para presos políticos e torturadores. Note-se, contudo, que a anistia não beneficiou os "dois lados": os condenados pelos chamados "crimes de sangue" saíram das prisões devido às mudanças da Lei de Segurança Nacional estabelecidas em $1978^{6}$ e não em decorrência da Lei de Anistia. Por outro lado, os militares saíram impunes: jamais foram indiciados por seus crimes, nem mencionados nas listas de anistiados publicadas pelos jornais da época.

Nesse contexto relativamente desfavorável, surgiram algumas iniciativas que buscavam exibir marcas simbólicas e efetivas de ruptura com esse passado traumático, preservando lugares caracterizados pela violência estatal do período ditatorial, conforme veremos a seguir.

\section{Portal do Presídio Tiradentes}

Um lugar emblemático da memória da repressão ditatorial na cidade de São Paulo é o Portal do Presídio Tiradentes, localizado na avenida de mesmo nome, próximo à Pinacoteca do Estado de São Paulo. O conjunto de edifícios que formava o presídio teve sucessivas utilizações ao longo de seus quase dois séculos de existência, entre elas a de abrigar a cadeia pública e cárceres para presos políticos. Em 1852, a Casa de Correção foi inaugurada, no bairro da Luz, após mais de vinte anos de espera para concluírem as obras do edifício, comportando também um depósito de escravos.

\footnotetext{
6 Essas mudanças estabeleceram penas menores para os crimes considerados contrários à Segurança Nacional (cf. Teles, 2005, p. 234).
} 
No século XX, especificamente em 1935, em decorrência da violência repressiva que se abateu sobre o Partido Comunista Brasileiro (PCB) e a Aliança Nacional Libertadora (ANL), o local passou a receber presos políticos num pavilhão especial. Em 1937, esse espaço foi transformado em Casa de Detenção, sendo dividido em prisão comum e especial. A superlotação logo se disseminou, contribuindo para a deterioração do edifício. Durante o Estado Novo, estiveram ali prisioneiros famosos, tais como o escritor Monteiro Lobato e José Maria Crispim, deputado comunista cassado em 1948 (Camargos e Saccheta, 1997, p. 493).

A partir de 1968, o Presídio Tiradentes voltou a ser um estabelecimento de detenção de dissidentes, chegando a abrigar cerca de 250 prisioneiros políticos ${ }^{7}$. Essa atividade foi retomada quando das prisões de metalúrgicos durante a greve de Osasco (SP) e da detenção de centenas de estudantes no XXX Congresso da União Nacional dos Estudantes 198 (UNE), em Ibiúna (SP). A ala especial ficava no Pavilhão I, mas, com a chegada de um grande número de prisioneiros, foi estendida ao Pavilhão II.

Normalmente, os presos políticos tinham direito ao "banho de sol", uma vez por semana, no espaço reservado do pátio interno por duas horas. Este local era chamado de "chiqueirinho" e ficava entre os Pavilhões I e II do complexo. O usufruto desse direito foi variável, de acordo com a época, conforme o testemunho de diversos ex-presos políticos. As celas eram compartilhadas em regime fechado, exigindo muita organização para estabelecer uma rotina capaz de mitigar a repetição e a monotonia. Eventualmente, era possível burlar esse funcionamento por meio de propinas ou de um carcereiro mais acessível (Teles, 2011, p. 220).

7 Cf. Cunha (2010). Segundo Maurice Politi (2009, p. 20), esse número pode ter variado entre 300 e 400 presos. 
A despeito das imposições do sistema penitenciário, o Presídio Tiradentes foi um espaço de resistência. Ali, os prisioneiros políticos cuidavam para que o cotidiano fosse repleto de atividades físicas, de lazer e culturais para usufruírem melhor de seu tempo e combater o isolamento e a imobilidade típicos do sistema carcerário. Nesse período, passaram pela instituição líderes comunistas históricos, tais como o ex-deputado federal Diógenes Arruda Câmara e Jacob Gorender, o historiador Caio Prado Jr., o artista plástico Sérgio Ferro, entre outros (Teles, 2011, pp. 220-21).

Em 1971, o presídio foi alvo de escandalosas denúncias sobre o tratamento dispensado aos presos comuns, levando o então procurador do Estado, Hélio Bicudo, a realizar uma visita ao estabelecimento, com o objetivo de apurar as execuções sumárias e torturas feitas pelo Esquadrão da Morte. Desde 1969, sucessivas denúncias de presos políticos contribuíram para tornar pública tal situação. Bicudo iniciou um processo contra o delegado Sérgio Paranhos Fleury, no qual determinava a apuração das atividades do Esquadrão (Bicudo, 2006). A ação impetrada na Justiça Civil contra Fleury chegou ao Supremo Tribunal Federal em março de 1971, sendo um dos quatro processos movidos contra o grupo, encaminhados pelo Ministério da Justiça (Pereira, 2010, p. 141). Fleury teve sua prisão preventiva decretada e foi mantido confinado nas dependências do Departamento Estadual de Ordem Política e Social (DEOPS-SP) entre outubro de 1973 e janeiro de 1974, mas o processo não prosperou ${ }^{8}$.

Em maio de 1973, o edifício do Presídio Tiradentes foi desativado para dar lugar às obras do metrô, de uma agência da Caixa Econômica Estadual e do Teatro Franco Zampari, da emissora de televisão TV Cultura. Naquele ano, uma vistoria no edifício feita por engenheiros designados pela

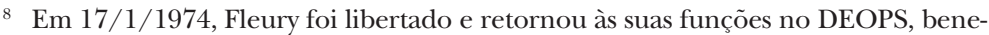
ficiando-se da Lei $\mathrm{n}^{\circ} 5.941$, de 22/11/1973, que determinava a dispensa de prisão preventiva àqueles que tivessem "bons antecedentes" (cf. Biocca, 1974, pp. 248-50).
} 
Corregedoria dos Presídios e da Polícia Judiciária detectou risco iminente de desabamento e incêndio em face da precariedade do local ${ }^{9}$. Na ocasião, a maioria dos presos políticos remanescentes foi transferida para o Presídio do Hipódromo, enquanto outros se juntaram à parcela de presos considerados "perigosos" que se encontrava confinada na Casa de Detenção (Carandiru) desde a greve de fome de $1972^{10}$. Ao ser demolido, restaram apenas os imensos tijolos usados nos pisos exteriores e o arco de granito da entrada do presídio, construído na década de 1930.

Em 1985, em decorrência das mudanças políticas do país, o portal foi tombado pelo Conselho de Defesa do Patrimônio Histórico (Condephaat) ${ }^{11}$, sob o governo de Franco Montoro. A solicitação partiu do Sindicato dos Jornalistas, a pedido das entidades organizadoras do Prêmio Vladimir Herzog de Anistia e Direitos Humanos ${ }^{12}$. No pedido de tombamento, as entidades justificaram-no por considerarem o portal 200 uma referência da história política do Brasil, da memória da repressão estatal e da resistência à mesma. O pedido assinalava a relevância de sua preservação enquanto denúncia da violência vivida naquela instituição e como instrumento de sobrevivência dessa memória "que muitos querem ver apagada”, a exemplo do que ocorrera com o próprio edifício (Condephaat, 1985, pp. 3-6). O parecer de 30 de setembro de 1985, do conselheiro do Condephaat e professor de sociologia da USP Lucio Kowarick, reiterou essa avaliação.

\footnotetext{
9 Cf. notícia "Presídio Tiradentes fechado para sempre" (1973).

${ }^{10}$ A reunificação dos presos políticos de São Paulo ocorreu apenas em março de 1975, quando foram transferidos para o Presídio Romão Gomes (cf. Teles, 2011).

${ }^{11}$ O pedido de tombamento foi encaminhado em 25/10/1984 e regulamentado pelo Secretário de Estado da Cultura de São Paulo Jorge da Cunha Lima, através da Resolução SC-59, de 25/10/1985 (cf. Condephaat, 1985, p. 85).

${ }^{12}$ Entre as 15 entidades estavam: Comitê Brasileiro pela Anistia (CBA-SP), Comissão Justiça e Paz (CJP-SP), Comitê Brasileiro de Solidariedade aos Povos da América Latina (CBS), Ordem dos Advogados do Brasil (OAB-SP), Associação Brasileira de Imprensa (ABI-SP), Partido dos Trabalhadores (PT-SP) (cf. Condephaat, 1985, pp. 4-6; disponível em: <www.arquivultura.fau.usp.br>).
} 
Considerando o valor histórico do Arco da Pedra enquanto símbolo da luta contra o arbítrio e a violência, é meu parecer que ele deva ser tombado e, posteriormente, transformado em monumento público. Sendo arco, é forçosamente uma passagem, que simboliza o esforço atual para a plena redemocratização do país (Condephaat, 1985, pp. 74-75).

Na data em que se completavam dez anos do assassinato do jornalista Vladimir Herzog, em 25 de outubro de 1985, foi inaugurada uma placa de bronze sob o arco do portal, com a seguinte inscrição: "A todos os homens e mulheres que, no Brasil, ao longo da História, lutaram contra a opressão e a exploração - pela liberdade" (Camargos e Sacchetta, 1997, p. 485). Como parte das atividades, foi organizada uma exposição de trabalhos artísticos, fotos, tapeçarias e textos de presos políticos na ABI, chamada Pequenas Insurreições - Memórias, cuja curadoria ficou a cargo do jornalista e ex-preso político Alípio Freire (Condephaat, 1985, p. 38).

Alguns militantes e sobreviventes se recordam do ato de inauguração da placa, tal como testemunhou o ex-preso político Carlos Russo Júnior. Em suas lembranças, ele sublinhou o sentido da recuperação da memória do local, caracterizado pela violência contra dissidentes e a população mais carente, assim como do próprio ato, marcado pelo reencontro da militância.

Lembro-me que compunha a coordenaçao do PT de São Paulo e considerei o ato algo muito interessante, porque havia gente de diversos grupos políticos. As divergências do passado já estavam distantes naquele momento. [...] Para mim, o Tiradentes foi um dos presídios em que estive preso, tenho muitas outras lembranças da Casa de Detenção e da Penitenciária. O Tiradentes é, para mim, mais uma 
referência da exclusão social e da violência contra os pobres. É mais presente para mim a lembrança do pessoal do Fleury indo até lá para buscar os presos comuns, que eram retirados no meio da noite para serem assassinados pelo Esquadrão da Morte. Na minha perspectiva, estava preso lá por uma opção pessoal e consciente, sabia dos riscos da militância; enquanto os pobres estavam naquele lugar devido às terríveis circunstâncias impostas pela desigualdade social. Foi isso que ficou gravado de maneira mais forte em mim... e acho que vem daí muito de sua importância enquanto lugar a ser lembrado... (Russo Jr., 2015).

Familiares de mortos e desaparecidos políticos também estiveram presentes ao ato para lembrar aqueles que não sobreviveram à repressão da ditadura e divulgar sua luta, conforme o cartão postal produzido à época, assinado pelos "Familiares de desaparecidos políticos da Guerrilha do Ara202 guaia", com os seguintes dizeres:

No golpe militar de 1964 e durante a ditadura de Vargas, centenas de brasileiros foram encarcerados neste presídio como presos políticos. Fundado em 1852, o presídio foi demolido em 1972 [sic], sendo este portal preservado, e tombado em 1985, pelo Patrimônio Histórico em memória dos heróis que lutaram pela liberdade ${ }^{13}$.

Durante alguns anos, os familiares depositaram flores sob a placa do portal no dia de finados, no dia do aniversário do início da Guerrilha do Araguaia ou no dia do desaparecimento de algum militante, tal como na foto do cartão postal. Anos mais tarde, a placa foi roubada, possivelmente devido ao alto valor de venda do bronze, tendo em vista que o portal está localizado numa região

${ }^{13}$ Cf. acervo pessoal de Criméia A. S. de Almeida. 
bastante degradada; ou, talvez, grupos paramilitares a tenham roubado.

$\mathrm{Na}$ atualidade, o portal permanece sem placa, sem palavras ou qualquer referência ao passado de violência e iniquidades que marcaram a existência do edifício que abrigou o presídio. Tal contexto impõe o questionamento sobre a capacidade do portal de transmitir as memórias e experiências vividas naquele local, remetendo-nos às vicissitudes relativas ao modo como temos lidado com o legado da ditadura no Brasil.

Esquecido por algum tempo, o Portal do Presídio Tiradentes voltou ao cenário político em 1997, quando foi lançado o livro Tiradentes, um presídio da ditadura, contendo os testemunhos de ex-presos políticos que estiveram confinados naquela instituição. Organizado por três ex-prisioneiros, o livro chamou a atenção pelos depoimentos ricos em memórias do cotidiano da vida ali, ainda que demasiadamente curtos, assim como pela ausência de uma amostragem mais abrangente (Freire, Almada e Ponce, 1997).

Alguns anos depois, o portal do Tiradentes despontou no cenário cultural através da exposição dos artistas alemães Horst Hoheisel e Andreas Knitz da instalação chamada Pássaro Livre / Vogelfrei. Realizado no segundo semestre de 2003, no Octógono da Pinacoteca do Estado de São Paulo, o evento se beneficiava de uma retomada da temática relativa à memória da ditadura a partir de 2002.

Na instalação do Octógono, localizada no centro deste espaço panóptico, os artistas construíram em escala 1:1 uma cópia do Portal do Presídio Tiradentes, realizada com estruturas de metal e em formato de gaiola ${ }^{14}$. Por meio da obra, a ruína em pedra do portal foi citada e metamorfoseada em prisão (Seligmann-Silva, 2004, p. 33). O portal passou

${ }^{14}$ Veja a respeito, inclusive imagens do Portal e sua réplica, o ensaio de Fulvia Molina neste dossiê. 
a lembrar o prédio, já inexistente e ruína "invisível” para grande parte da população. Durante a exposição, o "portal-prisão" serviu de abrigo para doze pombos, os quais eram libertados um a um a cada final de semana por ex-presos políticos do presídio.

No ato de inauguração da exposição, Alípio Freire relatou aos presentes memórias e histórias sobre o presídio, ao lado das fotos policiais de perseguidos políticos que passaram por lá, afixadas nas paredes do Octógono. Nesse ato de memória, a invisibilidade do portal da avenida Tiradentes tornou-se opaca, ganhando novamente "densidade e peso" (Seligmann-Silva, 2004, p. 34).

A despeito dos esforços de preservação do Portal do Presídio Tiradentes - atualmente ele faz parte do circuito turístico da cidade -, terminada a exposição, o local que o abriga volta à sua condição de sombra do passado e ruína "invisível" para a maioria da população.

\section{Memorial da Vala de Perus: a homenagem aos mortos e desaparecidos políticos}

O segundo ato memorialístico fundamental sobre a repressão da ditadura no Brasil foi a abertura da vala clandestina de Perus, em setembro de 1990. Esse evento pautou-se pela busca dos restos mortais de militantes assassinados pelos órgãos de segurança daquele período, ganhando ampla repercussão junto à opinião pública, com efetivas consequências nas investigações daqueles crimes (Teles, 2012).

Em seguida à abertura da vala clandestina, iniciaram-se as escavações e pesquisas de antropologia forense, as quais foram acompanhadas pela instauração de uma Comissão Parlamentar de Inquérito (CPI) na Câmara Municipal de São Paulo, visando apurar o que ocorreu em Perus e demais cemitérios da cidade. A abertura da vala motivou a descoberta de outras valas que escondiam restos mortais de militantes assassinados no Rio de Janeiro e em 
Pernambuco e a realização de escavações arqueológicas em outros estados.

Ressalte-se que, durante seis meses, a CPI procurou desvelar os mecanismos através dos quais tornou-se possível a manutenção, em segredo, das 1.049 ossadas da Vala de Perus, desde 1976. O trabalho de investigação obteve informações sobre como os militares, a polícia e os médicos legistas do Instituto Médico Legal (IML) articularam-se para ocultar os cadáveres e suas respectivas causa mortis.

O projeto Brasil Nunca Mais já havia denunciado a participação de policiais e médicos na falsificação de laudos necroscópicos e na ocultação de cadáveres para acobertar marcas de tortura, mas pouco se sabia. As investigações da CPI trouxeram à luz o esquema montado para falsificar os laudos e enterrar militantes com nomes falsos nos cemitérios de São Paulo. Essas investigações motivaram outras, de modo que sete ossadas de militantes assassinados durante a ditadura puderam ser identificadas pela Universidade de Campinas (Unicamp), entre 1992 e 1993. Nesse período, iniciou-se, também, um Inquérito Policial na Delegacia Seccional Oeste de São Paulo para apurar as responsabilidades relacionadas à vala clandestina.

A repercussão nacional desses fatos favoreceu a pesquisa nos arquivos do IML de São Paulo, organizada pelos familiares de mortos e desaparecidos políticos. O mesmo veio a acontecer no Rio de Janeiro. A pedido dos familiares, em 1991, o Presidente Collor promoveu a abertura dos arquivos das polícias políticas, os DOPS (Departamentos de Ordem Política e Social). Esse processo culminou na criação da Comissão de Direitos Humanos do Congresso Nacional e a promulgação da Lei dos Mortos e Desaparecidos Políticos (Lei nº 9.140), em 1995.

Um balanço dessa experiência indica que produziu alguns desdobramentos institucionais mais consistentes, tais como a recomendação para a desvinculação do IML da 
polícia estadual, a reorganização dos cemitérios municipais, a devolução dos arquivos dos DOPS aos estados e a regulamentação da Lei de Arquivos (Lei n ${ }^{\circ} 8.159 / 91$ ) - a despeito de seus limites (revogada pela Lei de Informação ${ }^{15}$ ). Em sentido inverso ao do Brasil Nunca Mais, que reuniu grande fonte documental oriunda de registros oficiais sobre os crimes da ditadura, a apuração dos fatos na CPI de Perus envolveu uma rara profusão de depoimentos de vítimas, médicos legistas, torturadores e agentes da repressão daquele período. Acrescente-se que o registro dos depoimentos caminhou lado a lado à verificação dos dados da pesquisa feita nos arquivos policiais, tais como os do IML-SP e do Serviço Funerário Municipal.

As escavações decorrentes da abertura da Vala de Perus fizeram emergir algumas das mais emblemáticas memórias da ditadura, reforçando a relação entre memória e atividade arqueológica, especialmente no que diz res206 peito aos crimes da ditadura. Frequentemente, os estudos sobre memória incluem analogias arqueológicas e metáforas de exumação, as quais se difundiram com os estudos freudianos do inconsciente enquanto camada subterrânea, de difícil acesso direto da mente, estabelecendo aproximações com o caso brasileiro (Freud, 1998).

À comoção gerada pelas imagens de coveiros desenterrando centenas de sacos contendo ossos, divulgadas nos jornais, emissoras de televisão e cinemas, somaram-se os esforços dos familiares que passaram anos compilando dados e divulgando as denúncias sobre os crimes do período. Note-se que, somente na vala clandestina de Perus, foram encontradas ossadas devidamente armazenadas em sacos plásticos, o que se mostrou fundamental para a realização dos trabalhos de identificação.

\footnotetext{
${ }^{15}$ Cf. Lei no 12.527, de 18/11/2011, disponível em: <http:/ /www.planalto.gov.br/ ccivil_03/_ato2011-2014/2011/lei/112527.htm>.
} 
Com a aproximação do término do mandato da Prefeita Luiza Erundina (1989-1993), temia-se que as investigações sobre as ossadas encontradas em Perus e demais locais fossem paralisadas. Nesse contexto, a prefeitura de São Paulo, reconhecendo o trabalho feito e aquele terreno como local de recordação, lançou em 1992 o edital do concurso de projetos para erguer um memorial onde se encontrava a vala clandestina.

A edificação de um memorial dedicado aos mortos e desaparecidos políticos foi possível graças ao protagonismo dos familiares na abertura da vala e nas investigações posteriores. O processo de construção desse memorial, relativamente desconhecido e marginalizado, reflete as vicissitudes vividas pelos familiares e ativistas das demandas por "verdade e justiça" no Brasil. Tal situação contrasta com a importância das investigações decorrentes da abertura da vala mas, sobretudo, com a prática de resgate histórico e reparação social levada a cabo em outros países latino-americanos, onde a apuração factual e judicial desse período adquiriram grande relevância, bem como a construção de locais de recordação.

Esse quadro emerge dos relatos dos protagonistas dessa história registrados aqui, conforme o testemunho de Suzana K. Lisboa, esposa de Luis Eurico Tejera Lisboa - integrante da Ação Libertadora Nacional (ALN), desaparecido em setembro de 1972 e enterrado como indigente em Perus -, primeiro militante a ser identificado no país, em 22 de agosto de 1979, durante a votação da Lei de Anistia no Congresso Nacional (Almeida et al., 2009, pp. 367-71).

A ideia de fazer o memorial surgiu entre os familiares que compunham a comissão de trabalho sobre a vala de Perus, na prefeitura. Queríamos inaugurar o memorial no governo da Erundina para homenagear tanto os mortos e desaparecidos políticos, quanto a própria prefeita, pelo 
empenho com que ela nos apoiou. [...] Depois de diversos problemas, decidiu-se pelo projeto do Ricardo Ohtake, mas tudo ocorreu muito em cima da hora, ao final do mandato dela. Até a inauguração foi rápida e discreta (Lisboa, 2014).

O testemunho do arquiteto Ricardo Ohtake, autor do projeto do memorial, faz menção ao contexto e às adversidades enfrentadas para edificá-lo:

A prefeitura fez um concurso..., mas aí aconteceu o inesperado. Depois de escolhido o projeto, descobriram numa revista um monumento, não sei de onde, que era exatamente o mesmo desenho do cara, cujo projeto havia sido escolhido. Acho que ele viu aquilo e ficou com a ideia na cabeça, sabe? Acho que a intenção não era plagiar alguém. Bom, aí anularam o concurso e chegaram até mim, dizendo que não havia tempo para fazer outro concurso, e me pediram para que eu fizesse um novo projeto. [...] Por intermédio da Dulce Maia, conheci alguns familiares que me pediram para criar o cartaz da missa feita em homenagem aos primeiros militantes, cujas ossadas haviam sido identificadas em Perus. Eles me convidaram para ler um documento durante a missa e aí, depois, veio a ideia de fazer o memorial (Ohtake, 2015).

No final de 1992, o memorial foi construído a partir do projeto de Ricardo Ohtake. A obra é composta basicamente de uma extensa fissura no chão, na forma de uma cicatriz, construída onde outrora ficava a vala clandestina. Essa fissura foi preenchida por cimento e sua superfície apresenta-se pintada da cor roxa/lilás. Por cima da fissura, cruzando-a, erigiu-se um muro vermelho. Olhando de cima, o muro faz lembrar as faixas de sinalização que designam proibição, características das placas de trânsito. De acordo com 
Ohtake, com aquele muro vermelho, ele quis representar o desejo de "nunca mais" sermos obrigados a presenciar assassinatos e a ocultação de cadáveres, tais como acontecia na ditadura. Ele próprio explica as ideias que pautaram o projeto:

Em 1991, eu tinha feito a arte do cartaz da missa, no qual havia uma espécie de vala, em roxo, e uma tarja vermelha atravessando por cima, tal como a do sinal de proibido. Eu pintei a vala em roxo/lilás, porque ela era diferente da cor comum da terra. Esta não é uma cor que se vê muito na natureza e eu quis colocar uma que fosse além da natureza! [...] Bom, quando me chamaram para fazer o projeto do memorial, eu usei essa ideia: eu construí uma parede no lugar da tarja vermelha. Eu a fiz em curva para ficar espacialmente mais legal e, no espaço correspondente à vala, coloquei um pó roxo. Depois, pediram-me para pôr um texto da Luiza e dos familiares. Foi tão corrido que o pessoal teve que ditar o texto por telefone! O serviço funerário executou parte do trabalho e ainda sobrou um dinheiro, que doei aos familiares (Ohtake, 2015).

A inscrição registrada no muro do memorial, assinada pela então Prefeita Luiza Erundina e pela Comissão de Familiares de Mortos e Desaparecidos Políticos, indica certo otimismo ingênuo, mas procura sublinhar a magnitude dos crimes praticados pela ditadura, tal como se pode ler a seguir:

AQUI, OS DITADORES TENTARAM ESCONDER OS DESAPARECIDOS POLÍTICOS, AS VÍTIMAS DA FOME, AS VÍTIMAS DA VIOLÊNCIA DO ESTADO POLICIAL E DOS ESQUADRÕES DA MORTE E, SOBRETUDO, OS DIREITOS DOS CIDADÃOS POBRES DA CIDADE DE SÃO PAULO. FICA REGISTRADO QUE OS CRIMES CONTRA A LIBERDADE SERÃO SEMPRE DESCOBERTOS! 
Ohtake possui uma relação especial com essa temática, pois, no tempo em que cursou arquitetura na USP, conviveu com amigos engajados na militância e que, posteriormente, foram assassinados pela repressão ditatorial. Seu melhor amigo na faculdade era Antonio Benetazzo, então estudante de arquitetura e de filosofia. Os dois ingressaram na universidade em 1964 e logo iniciaram uma forte amizade (Ohtake, 2015). Benê, tal como era conhecido, acabou se transformando em dirigente do Molipo (Movimento de Libertação Popular). Ao ser preso, em outubro de 1972, foi levado ao DOI-Codi/SP (Destacamento de Operações de Informações - Centro de Operações de Defesa Interna) (Almeida, 2009, p. 385) e, depois, a um centro clandestino de extermínio - o sítio 31 de março (Godoy, 2014, pp. 300-14). Foi assassinado após sessões de tortura e enterrado como indigente no cemitério de Perus. As diversas versões oficiais de sua morte, divulgadas na imprensa da época, davam conta 210 de que ele havia se suicidado (Almeida, 2009, pp. 385-86).

$\mathrm{O}$ amigo Ricardo se lembra de que, além da política, Benê se dedicava às artes, sobretudo à pintura e à fotografia, cujo talento e inteligência o marcaram profundamente (Ohtake, 2015). Ele foi um dos criadores de um dos primeiros jornais alternativos do país - O Amanhã -, era professor de história da arte, ator, cenógrafo e artista gráfico (Almeida, 2009, pp. 384-85). Eram tão amigos que continuaram se vendo regularmente depois que Benê caiu na clandestinidade. E mais, foi Ohtake quem levou Benê para o aeroporto de Viracopos, em Campinas (SP), quando este viajou para Cuba a fim de realizar treinamento militar. Quando voltou, Benê ainda se encontrou duas vezes com Ohtake, o qual foi preso em novembro de 1971 e interrogado sobre suas relações com o amigo e outros estudantes da $\mathrm{USP}^{16}$.

${ }^{16}$ Cf. Ohtake (2015) e os seguintes documentos do arquivo do DEOPS/SP: 30-Z160-10922, 52-Z-0-8496, 52-Z-0-23481, 52-Z-82-1061. 
A atmosfera de medo gerada pelo terror disseminado pelo Estado, naquele período, faz do memorial um registro da violência estatal, combinando memória e esquecimento, trabalho de recordação e recalque. A vala comum e a fissura representada no memorial se transformaram, simultaneamente, em imagem e ferida (o mesmo que trauma, palavra de origem grega). Um rastro da violência que persiste, advertindo-nos para não esquecer e para que nunca mais aconteça, mas cuja conservação é condição para que se torne portador de novas significações e sumário de outras narrativas do passado (Assmann, 2011, p. 352).

$\mathrm{Na}$ medida em que o memorial se volta àqueles considerados "indesejáveis" durante a ditadura, sobretudo aos desaparecidos políticos, ele injeta outra visão da história na cena da comemoração pública, favorecendo a reflexão crítica do passado recente. A memória do trauma, assim como a própria recuperação dessa história revelam sua precariedade e sua capacidade de resistência, tornando-se o principal recurso que, eventualmente, pode-se interpor ao sofrimento e à injustiça.

A vala clandestina de Perus nos vincula à violência contra dissidentes e a população pobre. Trata-se de um local demarcado pelos sobreviventes, mas também da manifestação de uma memória involuntária que "traz à luz uma descoberta tardia repentina” (Assmann, 2011, p. 358) por meio, por exemplo, da descoberta dos restos mortais de cerca de 300 crianças, vítimas da epidemia de meningite censurada pela ditadura. Para os sobreviventes e familiares, ela preserva a violência "de um acontecimento que permanece, como um passado que não se esvai, que não logra guardar distância” (Assmann, 2011, p. 350). A vala é uma ferida que não pode cicatrizar.

A Vala de Perus e o próprio memorial são a asseguração arqueológica dos vestígios de um passado traumático que se quis soterrado. É um local que estabelece uma ligação com esse passado, uma ligação entre presença e 
ausência, mas que insiste em manter separados o aqui e o outrora. É um local que, combinado à recuperação de sua história, suscita estranheza e nos faz perceber "o afastamento e a distância irrecuperável do passado" (Assmann, 2011, pp. 357, 360).

Para além da presença da palavra escrita na pedra, tal como nas antigas práticas funerárias e de comemoração, é patente o valor atribuído à visão nesse ato de rememorar. Com seu aspecto simples e direto, o Memorial da Vala de Perus procura abrir nossos olhos para um passado que resistimos a dirigir nosso olhar. Familiares e militantes aposta(ra)m na força das palavras, dos gestos e dos rituais efêmeros, num esforço de recordar o passado de maneira (cri)ativa.

Os familiares de mortos e desaparecidos políticos investiram na capacidade de criar rituais e atualizar símbolos da resistência à ditadura. Durante os anos de 1990, o memorial foi o palco onde dom Paulo Evaristo Arns celebrou missas no dia de 212 finados em homenagem "às lutas de resistência e àqueles que não estão mais presentes”, reeditando as missas celebradas na Praça da Sé nos anos de 1970. A cada ano, renovava-se a pauta a ser abordada no ato público que se seguia à celebração.

Esse memorial compõe o processo de construção da identidade dos sobreviventes e de familiares, mas é também parte da paisagem histórica da cidade ${ }^{17}$. Sabemos que as atividades relativas a recomeçar e recordar permeiam o percurso das lutas políticas e das significações culturais, mas a "persistência dos locais" pode contribuir para o estabelecimento de uma "memória de longa duração" (Assmann, 2011, pp. 358-59) sobre a repressão ditatorial ${ }^{18}$. Note-se,

${ }^{17}$ É digno de nota que o memorial, além de estar localizado num distrito muito distante, não consta do Inventário de Obras de Arte em Logradouros Públicos da Cidade de São Paulo, disponível em: <www.patrimoniohistorico.sp.gov.br $>$. Acesso em: 25 jul. 2015.

${ }_{18}$ Por falta de espaço, não trataremos da Estela que homenageia os mortos e desaparecidos políticos no hall de entrada do Centro Cultural Maria Antonia, inaugurada em 1994. 
porém, que a despeito da relevância da abertura da Vala de Perus, passados 25 anos, os trabalhos de identificação dos restos mortais ali encontrados ainda não foram concluídos (Bocchini, 2015a, 2015b).

\section{Memorial Carlos Marighella}

Outro memorial representativo do trauma relativo à repressão ditatorial em São Paulo é o Memorial Marighella, instalado num bairro "nobre" da cidade, o Jardim Paulistano.

Em 3 de novembro de 1999, um dia antes de se completarem trinta anos da morte de Carlos Marighella, um homem impediu a colocação da pedra/escultura que constitui o memorial em sua homenagem, em frente ao prédio onde residia, situado à alameda Casa Branca, 815 . O homem, que se identificou como oficial da reserva do Exército, disse, ameaçando os presentes: "Se for preciso, darei até tiros. Não quero um monumento a um bandido em frente da minha casa." Nesse local o líder da Ação Libertadora Nacional (ALN) foi assassinado em 1969, atingido por quatro tiros numa emboscada comandada pelo delegado Sérgio Fleury.

Quando de sua inauguração, o granito polido trazia a inscrição "Aqui tombou Carlos Marighella, assassinado em 4 de novembro de 1969 pela ditadura militar”. Em consequência da reação provocada, a obra foi deixada sobre a calçada, em vez de ser instalada sob um resto de árvore cortada, como pretendia seu autor, o arquiteto Marcelo Carvalho Ferraz. De acordo com seu relato, isso não deveria ter acontecido, pois aquele local é considerado um marco na história da cidade e do país e, naquela altura, o Estado já havia reconhecido sua "culpa pelo assassinato" de Marighella e indenizado a família ${ }^{19}$.

${ }^{19}$ Cf. notícia "Homenagem a Marighella causa polêmica em SP" (1999). 
A polêmica se estendeu inclusive à questão do local exato onde ocorrera a morte de Marighella. Ao considerar que o líder revolucionário foi assassinado naquele quarteirão, Ferraz afirmou que colocar a escultura ao lado da árvore serrada tinha um apelo simbólico forte. Na ocasião, a companheira de muitos anos de Marighella, Clara Charf, considerou que os militares, no futuro, reconheceriam seu valor, "assim como reconheceram o de Tiradentes" (Angiolillo, 1999).

As polêmicas permearam a vida e a morte de Marighella (Magalhães, 2009). Estas já haviam alcançado particular relevo na Semana da Pátria de 1997, quando o Presidente Fernando Henrique Cardoso assinou o decreto que indenizava a família de Marighella e a de Carlos Lamarca. Na época, o general Oswaldo Pereira Gomes, representante das Forças Armadas na Comissão Especial de Mortos e Desaparecidos Políticos (CEMDP), lamentou a decisão.

214 A despeito da reação à instalação do memorial, no dia seguinte, 4 de novembro de 1999, o ato em memória dos trinta anos da morte de Marighella foi realizado, e familiares e companheiros depositaram flores no monumento, entre eles, o filho Carlos Marighella Augusto e Clara Charf. A inauguração da escultura era parte das homenagens promovidas por um grupo de militantes e intelectuais, entre eles Mino Carta, Ricardo Ohtake, Oscar Niemeyer, Lígia Fagundes Telles, Fábio Konder Comparato e Antonio Candido. Esse grupo solicitou autorização ao então Prefeito de São Paulo, Celso Pitta, para utilizar o espaço para essa homenagem. Naquele dia, o Diário Oficial do Município publicou o decreto que integrou a escultura ao patrimônio municipal, destinando aquela área à sua instalação.

$\mathrm{O}$ ato contou com alguns discursos emocionados. Ao lado da escultura, falaram companheiros, amigos e admiradores, como Antonio Candido, entre outros (Castro, 2015). A proposta partiu, inicialmente, de um grupo de 
ex-militantes da ALN, vários deles, inclusive, haviam permanecido por longos períodos de reclusão em presídios da cidade. Ricardo Ohtake, então Secretário do Verde e Meio Ambiente do Município de São Paulo, foi decisivo para garantir a formalização da proposta de criação do memorial. Procurado para colaborar, ele se recorda de que recebeu um telefonema e, em seguida, dirigiu-se ao Prefeito Celso Pitta:

Expliquei a proposta e perguntei o que ele achava. Ele aprovou a ideia imediatamente e, então, perguntei-lhe o que deveria fazer para acelerar o processo. O prefeito encaminhou-me para uma assessora muito solícita e, assim, foram resolvidas as tratativas burocráticas. Lembro-me de que eu e o filho do Marighella puxamos uma fitinha na inauguração [risos]... (Ohtake, 2015).

Com o advento do século XXI, assistiu-se ao surgimento de nova onda de retomada das memórias do período ditatorial. Não obstante, a polêmica em torno da localização do Memorial Marighella persistiu. De acordo com as lembranças de Carlos Russo Júnior:

Depois da polêmica, o memorial foi destruído [...]. Nos anos seguintes, continuamos fazendo encontros no local, no dia da morte de Marighella, sempre contando com a presença de militantes que faziam discursos lembrando episódios sobre ele etc. Esses encontros são sempre um ato livre e pautado por um tema atual... Para nós, o local se transformou num marco da militância ativa e corajosa de Marighella, num momento crucial da vida do país. E é também onde ele foi assassinado de maneira covarde pela turma do Fleury. Para nós, Marighella é um símbolo da resistência ao arbítrio ao longo de boa parte do século XX e é por isso que lembramos dele todos os anos (Russo Jr., 2015). 
De fato, pouco depois de inaugurada, a escultura em granito foi destruída e, após oito meses, foi retirada do local - diversos moradores solicitavam que não fosse recolocada naquela calçada (Russo Jr., 2015). Não obstante as pressões, a reinauguração do memorial ocorreu em 4 de novembro de 2004. A solenidade organizada por familiares, militantes e companheiros de Marighella lembrou os 35 anos de sua morte. Seus amigos e companheiros fizeram discursos e leram trechos de textos e poemas.

Após o evento, Clara Charf manifestou sua convicção de que a história de Marighella e daqueles que resistiram à ditadura militar não seria esquecida, pois o ato contara com a presença de muitos jovens. Segundo a sua percepção, o memorial deverá fortalecer o debate sobre a recuperação histórica e sobre o sentido da morte de Marighella, transcendendo a simples homenagem. Carlos Russo relembra que

[...] durante a reinauguração do memorial, li um pedaço de um conto meu, o qual espero poder publicar em livro, um dia, e isso foi emocionante. Lembro-me que a placa desapereceu da pedra, pelo menos, duas vezes. Na época, eu morava lá perto e sempre passava em frente do memorial para ver se ele ainda estava com a placa. Infelizmente, não me lembro como fizemos para recolocá-la. Sei que, agora, o memorial está novamente sem placa (Russo Jr., 2015).

Depositar flores diante do Memorial Marighella todo dia 4 de novembro tornou-se um hábito de familiares e militantes, e transformou-se em um símbolo que transcende a função de suporte terapêutico para os sobreviventes. Estes têm reinventado, a cada ano, novas maneiras de tornar visível esse personagem histórico e a temática do "direito à memória e à verdade" no Brasil. As datas emblemáticas ganham maior visibilidade em períodos significativos, tais como quando se lembrou os quarenta anos do assassinato 
de Marighella, em 2009. Nessa data, Marighella ganhou o título de cidadão paulistano, In Memoriam, da Câmara Municipal de São Paulo e o ato em volta do memorial teve maior destaque.

O Memorial Marighella é um exemplo interessante das relações existentes entre história e memória, as quais criam tensões em uma dialética aberta, em face da qual esta se preserva das pretensões daquela de reduzir-lhe a um de seus objetos e, opostamente, do afã da "memória coletiva de avassalar a história com as comemorações impostas pelo poder político ou pelos grupos de pressão" (Ricoeur, 2007, p. 403). É digno de nota, porém, que mesmo com os esforços empenhados na preservação de sua memória, a escultura do Memorial Carlos Marighella permanece sem a placa, contendo a inscrição sobre o personagem histórico a quem homenageia, e sem referências que possam estabelecer um vínculo mais duradouro com a sua e a nossa história.

A despeito dos limites impostos pela transição pactuada, os "lugares de memória" aqui analisados favoreceram a constituição de uma consciência coletiva acerca da repressão ditatorial e do status de suas vítimas e sobreviventes. Não obstante, o Brasil mantém-se como modelo de impunidade e atraso na promoção de uma política de reconstituição factual dos crimes da ditadura, mesmo depois de concluídos os trabalhos da Comissão Nacional da Verdade (CNV, 2014).

Os mecanismos de denegação e bloqueio de processos de responsabilização permanecem dificultando a realização de um amplo e efetivo debate na sociedade brasileira sobre o legado da ditadura, apesar de alguns avanços mencionados anteriormente. De fato, o Brasil avançou a partir das experiências aqui relatadas, mas também não soube aproveitar a oportunidade para a geração de processos de justiça 
e responsabilização que efetivamente refletissem a real magnitude da violência estatal do período.

Essa realidade contribui sensivelmente para a irresolução dos conflitos relativos à época. Trata-se de uma "lógica astuta" do Estado brasileiro (Safatle, 2005, p. 34), pois, ao mesmo tempo que reconhece as demandas das vítimas e sobreviventes por reparações e políticas públicas de memória, desloca para a periferia do universo político a apuração dos crimes cometidos pelo Estado durante a ditadura, o debate sobre os sentidos dessa experiência, bem como sobre a responsabilização por tais crimes. Nesse sentido, é de se notar o quanto a experiência brasileira de (re)democratização contrasta com a de diversos países latino-americanos.

\section{Janaína de Almeida Teles}

é pesquisadora no Programa de Pós-Doutorado do Depar218 tamento de História da Universidade de São Paulo (USP) e bolsista da Fapesp.

\section{Bibliografia}

ALMEIDA, C. et al. (orgs.). 2009. Dossiê Ditadura: mortos e desaparecidos políticos no Brasil (1964-1985). São Paulo: IEVE/Imprensa Oficial. ANGIOLILLO, F. 1999. "Morador impede colocação de marco a

Marighella em SP". Folha de S.Paulo, 4 nov.

ARNS, P. E.; PROJETO BRASIL NUNCA MAIS. 1985. Brasil: Nunca Mais um relato para a história. Petrópolis: Vozes.

ARQUIDIOCESE de São Paulo, 1987. Perfil dos atingidos. Tomo III. Projeto Brasil: Nunca Mais. Petrópolis: Vozes.

ASSMANN, A. 2011. Espaços de recordação: formas e transformações da memória cultural. Campinas, SP: Ed. Unicamp.

BICUDO, H. 2006. Meu depoimento sobre o Esquadrão da Morte. 2. ed. São Paulo: Martins Fontes.

BIOCCA, E. 1974. Estratégia do terror. A face oculta e repressiva do Brasil.

Lisboa: Iniciativas Editoriais.

BOCCHINI, B. 2015a. "Ex-presos políticos criticam ausência da vala de Perus no relatório da CNV". Agência Brasil, 31 jan. 
2015b. "Grupo já analisou 144 ossadas da vala clandestina do cemitério de Perus”. Agência Brasil, 10 fev.

CAMARGOS, M. M. de R.; SACCHETTA, V. 1997. "A história do presídio Tiradentes: um mergulho na iniquidade”. In: FREIRE, A.; ALMADA, I.; PONCE, J. A. de G. (orgs.). Tiradentes, um presídio da ditadura: memórias de presos políticos. São Paulo: Scipione.

CAPELATO, M. H. R. 2007. Memórias da ditadura militar argentina: um desafio para a história. São Paulo: [mimeo].

CNV - Comissão Nacional da Verdade. 2014. Relatório da Comissão Nacional da Verdade. Brasília: Presidência da República.

CONADEP - Comissão Nacional sobre o Desaparecimento de Pessoas. 2006. Informe Nunca Más. Buenos Aires: Eudeba.

CONDEPHAAT - Conselho de Defesa do Patrimônio Histórico. 1985. Estudo de tombamento do Arco do Presídio Tiradentes para transformá-lo em monumento público. São Paulo: Condephaat.

CRENZEL, E. 2008. La historia política del Nunca Más. La memoria de las desapariciones en la Argentina. Buenos Aires: Siglo Veintiuno.

FREIRE, A.; ALMADA, I.; PONCE, J. A. de G. (orgs.). 1997. Tiradentes, um presídio da ditadura: memórias de presos políticos. São Paulo: Scipione.

FREUD, S. 1998. Notas sobre um caso de neurose obsessiva (O homem dos ratos).

Rio de Janeiro: Imago.

GODOY, M. 2014. A casa da Vovó, uma biografia do DOI-Codi. São Paulo: Alameda.

"HOMENAGEM a Marighella causa polêmica em SP”. 1999. Diário do Grande $A B C, 3$ nov.

HUYSSEN, A. 2002. En busca del futuro perdido. Cultura y memoria en tiempos de globalización. México: FCE.

JELIN, E. 2002. Los trabajos de la memoria. Madrid: Siglo XXI.

LE GOFF, J. 1994. História e memória. 3. ed., Campinas, SP: Ed. Unicamp.

MAGALHÃES, M. 2009. Marighella, o guerrilheiro que incendiou o mundo. São Paulo: Companhia das Letras.

NORA, P. 1993. "Entre memória e história: a problemática dos lugares". Projeto História, n. 10, pp. 7-28.

PEREIRA, A. W. 2010. Ditadura e repressão. O autoritarismo e o Estado de direito no Brasil, no Chile e na Argentina. São Paulo: Paz e Terra.

POLITI, M. 2009. Resistência atrás das grades. São Paulo: Plena Editorial. "PRESÍDIO Tiradentes fechado para sempre". 1973. Folha de S.Paulo, 19 mar. RICOEUR, P. 2007. A memória, a história, o esquecimento. Campinas, SP: Ed. Unicamp.

SAFATLE, V. 2005. "Encontro marcado". Reportagem, n. 65. 
SELIGMANN-SILVA, M. 2004. "A arte de dar face às datas: a topografia da memória na arte contemporânea”. In: KNITZ, A. et al. (orgs.). A alma dos edificios / Die Seele der Gebäude / The soul of the buildings. São Paulo: Centro Universitário Maria Antonia (USP). . 2012. "Antimonumentos: a memória possível após as catástrofes".

In: FERREIRA, M. L. M.; MICHELON, F. F. (orgs.). Memória e esquecimento. Pelotas, RS: Ed. UFPel.

TELES, J. de A. 2005. Os herdeiros da memória: a luta dos familiares de mortos e desaparecidos políticos por "verdade e justiça” no Brasil. Dissertação de mestrado em História. Faculdade de Filosofia, Letras e Ciências Humanas da Universidade de São Paulo. 2011. Memórias dos cárceres da ditadura: as lutas e os testemunhos dos presos políticos no Brasil. Tese de doutorado em História. Faculdade de Filosofia, Letras e Ciências Humanas da Universidade de São Paulo. . 2012. "A constituição das memórias sobre a repressão da ditadura: o projeto Brasil: Nunca Mais e a abertura da Vala de Perus". Revista Anos 90, v. 19, n. 35.

TRAVERSO, E. 2007. El pasado, instrucciones de uso. Historia, memoria, política. Madrid: Marcial Pons.

WESCHLER, L. 1990. Um milagre, um universo: o acerto de contas com os torturadores. São Paulo: Companhia das Letras.

WINTER, J. 2006. "A geração da memória: as reflexões sobre 'boom da memória' nos estudos contemporâneos de história”. In: SELIGMANNSILVA, M. (org.). Palavra e imagem: memória e escritura. Chapecó, RS: Argos.

\section{Entrevistas}

CASTRO, C. de. 2015. Entrevista concedida a Janaína de A. Teles. São Paulo (SP), 23 jun.

CUNHA, C. A. L. 2010. Entrevista concedida a Janaína de A. Teles. São Paulo (SP), 23 abr.

LISBOA, S. K. 2014. Entrevista concedida a Janaína de A. Teles. São Paulo (SP), 6 out.

OHTAKE, R. 2015. Entrevista concedida a Janaína de A. Teles. São Paulo (SP), 17 mar.

RUSSO JR., C. 2015. Entrevista concedida a Janaína de A. Teles. São Paulo (SP), 16 mar. 


\title{
DITADURA E REPRESSÃO: LOCAIS DE RECORDAÇÃO E MEMÓRIA SOCIAL NA CIDADE DE SÃO PAULO
}

\author{
JANAÍNA DE ALMEIDA TELES
}

Resumo: A transição brasileira para a democracia ocorreu sem rupturas evidentes. Sob a forte presença do legado ditatorial, a formação da memória sobre a repressão da ditadura teve dois eventos fundamentais, a publicação do projeto Brasil Nunca Mais e a abertura da Vala de Perus. A partir desses eventos fundacionais, o estudo tratado neste artigo oferece um panorama reflexivo sobre os primeiros locais de recordação do período preservados ou construídos na cidade de São Paulo. A despeito dos limites impostos pela transição pactuada, esses "lugares de memória" favoreceram a constituição de uma consciência coletiva acerca da repressão ditatorial e do status de suas vítimas e sobreviventes. A pesquisa realizada beneficiou-se de entrevistas inéditas, documentos pouco explorados e uma revisão da bibliografia existente sobre o assunto.

Palavras-chave: Ditadura; Memória; Locais de Recordação; Presos Políticos; Mortos e Desaparecidos Políticos.

\section{DICTATORSHIP AND REPRESSION: MEMORIAL SITES AND SOCIAL MEMORY IN THE CITY OF SÃO PAULO}

Abstract: The Brazilian transition to democracy occurred without notable ruptures. Under the strong legacy of the civil-military dictatorship, the historical recollection of the period includes two fundamental events: the publication of the project Brasil Nunca Mais and the opening of the graveyard of Perus. From these foundational events the main goal of this study is to offer a reflexive panorama of the first memorial sites of the period, preserved or built in the city of São Paulo. In spite of the limits imposed by the negotiated political transition, these memorial 
sites benefited the birth of the collective consciousness about the dictatorship repression and the social status of the victims and the survivors. This research is based on interviews with people directly involved in these events, rare documents and a review of the existing bibliography on the matter.

Keywords: Dictatorship; Social Memory; Memorial Sites; Political Prisoners; Dead and Political Disappeared.

Recebido: 31/07/2015 Aprovado: 19/08/2015 